\title{
Why Use Ads in the Foreign Language Classroom?
}

\section{Jonathan D. Picken}

Tsuda College

This article reviews recent work in the areas of language awareness, language play, and culture on the use of advertisements in foreign language teaching. The arguments for the use of advertisements are examined, examples of how advertising might be used in these areas are given, and suggestions are made regarding how advertising research could help to maximize the value of adbased materials in the three contexts considered.

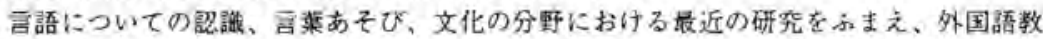
育における広告の使用について考察する。広告の使用を論し、上記の三つの分野での広告 使用例を举げる。爻らに、翼なる三つのコンテクストにおいて、いかに広告の研究が広告 を用いた教材の算を最大限に高めるかを提案したい。

he language-teaching profession has long had advocates of the classroom use of advertising as authentic material (e,g., Davis, 1997; Doering, 1993; Mollica, 1979), but their enthusiasm appears to have had little impact. Advertisements are still rarely used in mainstream EFL texts, and when they are, it is often for tried and true activities, e.g., related to job applications. There are many reasons for the scarcity of advertisements in pedagogical material but one of the most important is that until quite recently little research was available regarding their benefits. Leech (1966) and two highly critical books by Geis (1982) and Vestergaard and Schrøder (1985) were the main sources.

Since the early ' 90 s the situation has changed dramatically with books by Cook (1992), Goddard (1998), Myers (1994), and Tanaka (1994) mainly on consumer advertising, by Bruthiaux (1996) on classified advertising, and by Forceville (1996) on the visual language of advertisements. This boom in advertising research has allowed for increasingly informed discussions of the use of advertisements in the foreign language (FL) classroom, especially with reference to language awareness work, language play, and culture learning. Language awareness researchers have ar- 
gued that learners need to learn about language in addition to learning the language. Language play researchers have suggested that learners need opportunities to experiment and play with the language. Culture learning researchers have stressed that learners need to come to terms with the values and assumptions of a target culture and to find a place for themselves within its discourses. Thus, researchers in all three areas have stressed that advertising can be a valuable source of materials for these purposes. These developments suggest that language teachers will use ads more often and for a greater range of reasons in years to come.

To support an informed use of advertisements in the FL classroom, this paper critically examines arguments for the use of ads in FL teaching within the areas of language awareness, language play, and culture learning. In the following sections the relevant ideas will be summarized, examples of how ads might be used will be given, and the ideas will be related to advertising research by showing where research supports the ideas, where further research is desirable, and where caution is advisable.

\section{Ads and Language Awareness}

Language, as Yaguello (1998) has pointed out, is a "game (a structure) whose rules are frequently bent. It allows all kinds of cheating and hitting below the belt and it is quite impossible to define precisely the overall scope of what is allowed and what is not" (p. 17). This view of language suggests that knowledge of the rules is necessary, but so is an understanding of what happens when the rules are bent. Teachers and learners need to recognize what Jakobson (1988) has called the "poetic function" (p. 37) of language. McRae (1996) suggests this orientation when he argues for "a philosophy of language teaching which incorporates examples of text of any kind that demonstrate how language works within the rules and beyond the rules" (p. 20).

McRae is not suggesting that rules can be neglected. What he envisages is a balanced approach that "encourages an awareness of the language system and how it works at the same time as showing the range of flexibility the system allows for (and indeed encourages)" (p. 19). Language learning should, therefore, focus not just on the construing of meaning but also on "discussion, reflection, and consideration of meaning" (p. 20). For this purpose he advocates that language teaching should include work with creative language, which he refers to as literature with a small "I."

McCarthy and Carter (1994) make a similar argument when they propose that "literary text is an important vehicle for raising language awareness" (p. 117). Like McRae, they are not working with a narrow definition of literature. "Literary uses of language and the necessary skills for its 
interpretation go routinely with all kinds of text, spoken and written" (Carter \& McCarthy, 1995, p. 320). Poetic or literary uses of language are all around us. They are in the jokes, puns, and allusions of everyday conversation and newspaper headlines, in the speeches of politicians, in songs, in graffiti, in advertising copy, and, of course, in popular and canonical works of literature. Carter and Nash (1990) suggest that it is more profitable to think of literariness as a matter of degree and propose using six criteria to determine a text's degree of literariness.'

One important practical implication of this broad definition of literariness is that a wide range of discourses can be used to help learners develop language awareness, including advertising. A BMW advertisement from Coyne (1997) provides a good example of how ads can be used to do this, ${ }^{2}$ This advertisement consists of a small photograph of a BMW and a business letter purportedly written by John S. Miller of BMW America's marketing division to Mr. C. van Tune, editor of Motor Trend Magazine:

Dear Mr. van Tune:

Thank you for selecting the BMW 5 Series as Motor Trend's 1997 "Import Car of the Year." This is truly a prestigious honor. Especially considering this year's list of exceptional candidates.

Incidentally, I did notice that our car has not yet been returned. I've enclosed a photograph to aid in its identification.

$$
\begin{aligned}
& \text { Sincerely, } \\
& \text { John S. Miller, } \\
& \text { Marketing } \\
& \text { (Coyne, 1997, p. 65) }
\end{aligned}
$$

The literary aspect of this ad that is particularly relevant here is what Carter and Nash (1990) call re-registration. Literary language regularly "re-registers" or borrows language from other registers or genres. Auden's poem "The Unknown Citizen" "makes use of bureaucratic registers" (Carter and Nash, 1990, p. 38). Richardson's Pamela, an epistolary novel, exploits the genre of personal letters. In the same sort of way, this BMW ad exploits the business letter genre.

The interesting thing about the re-registration of the business letter is that the borrowing is not wholesale. The audience is expected to recognize that it is supposed to be a business letter but not to be fooled into thinking that it is real. ${ }^{3}$ The letter is simply a "form of disguise" (Leech, 1966, p. 100) and the ad would fail if the reader did not recognize this and ended up wondering why BMW had reprinted a letter of complaint about a car that had not been returned. 
The fact that the borrowing is partial and imperfect in this ad (and others) can be exploited in language awareness work. For example, the students could be instructed to (a) identify the text as a business letter, (b) enumerate the features that helped them identify it, (c) consider what features of it are "unbusinesslike," and (d) write an improved version.

The first three steps of the sequence would help to raise the students' awareness of the characteristics of business letters and of how the ad has played with these. In formal terms, the letter looks fine; it is laid out correctly and has all the elements that one would expect, from the letterhead to the closing. However, the letter's combination of the purposes of thanking the addressee and asking him to return a car seems odd. The personal "thank you" to the editor for selecting the BMW seems naive because normally an expert jury would have made the selection. The first paragraph contains a sentence without a finite verb. The first sentence of the second paragraph is weak and indirect. If BMW had provided a car for testing, they would have agreed on the conditions for doing so with Motor Trend, and this would be the moment to refer to the agreement. The final sentence about enclosing a photograph to aid in the car's identification is just silly, although it does allow the advertiser to include a visual of the product.

Because the letter's combination of gratitude and mild complaint strikes a discordant note, the writing task at the end of this four-part sequence could consist either of writing an appropriate response to the happy news about the award or of writing a polite but firm letter demanding the return of the BMW. In this way, the whole sequence would involve "reflection on language and the development of more explicit knowledge about languagen $^{\text {n }}$ and this would also "feed into the process of learning to use the language more proficiently" (McCarthy and Carter, 1994, p. 134). ${ }^{4}$

The use of literary devices in ads has been commented on widely (see, in particular, Cook, 1992; Leech, 1966; Myers, 1994), and this supports the idea that advertisements could be a valuable resource for language awareness work. At the same time, teachers also need to be aware of a major difference between advertising and other literary discourses, Advertising tends to be highly visual, and this can be a problem.

Medium dependence, or the degree to which a text depends on other media, especially visual ones, is actually the first of Carter and Nash's (1990) six criteria of literariness: "The more literary a text the less it will be dependent on another medium or media" (p. 38). This is an argument for saying that advertising, with its tendency to depend on visual elements to get its message across, is less literary than poetry, for example.

While visual elements may reduce the literariness of ads, they do not necessarily reduce their artistry. In some cases the picture mainly serves as 
a simple illustration of a product, but in other cases, the use of visuals is highly complex. Forceville (1996), for example, distinguishes two varieties of metaphor in advertising that are completely visual and a third that uses text and visual elements. In cases where a picture illustrates a product, the visual input is likely to help leamers, but dealing with more complex uses of visuals could require a degree of visual literacy that learners may not have. This problem should not be underestimated. Forceville (1996) discusses the case of a Chinese participant in an experiment on visual metaphor whose idiosyncratic responses were strongly influenced by failure to recognize vital components in some IBM ads. She mistook a beacon for a sailing boat and did not recognize a tuning fork.

The existence of this problem does not mean that teachers should avoid using ads for language awareness work. However, they should be aware of it and be prepared to deal with it, either by means of a judicious selection of ads that leamers can understand visually or by devising ways of helping learners to deal with the visual problems that they encounter.

Advertising researchers could contribute here by providing more complete analyses of the many complicated uses of visuals that can be found in advertising. Forceville (1996) provides a good discussion of earlier work in this area and also offers suggestions for future research. Research into the visual and verbal/visual literacy problems of FL learners is virtually non-existent (though see Goodman, 1996, and Hewings, 1991) and here again advertising researchers could contribute.

\section{Ads and Language Play}

"The ability to play with words is a measure of language proficiency" (Yaguello, 1998, p. 3). This connection between wordplay and language proficiency suggests another fascinating possibility; that play with the code can be a direct stimulus for language learning. Nash (1980) highlights this view when he describes the value of writing verse:

There is a paradox with which amateurs of verse will be acquainted: the more rigorous a compositional scheme, the greater its heuristic power, Rules and conditions, that is to say, enforce discoveries. The demands of a rhetorical figure, or any kind of linguistic prerequisite, urge the mind to rehearse and methodologically ransack its store of vocabulary. In this process, phonetic and kinetic (rhythmic) features may be compelling stimuli. Consider, for example, Edward Lear's comic denunciation of the monks of Mount Athos: Those muttering, miserable, mutton-bating, man-avoiding, misogynic, morose and merrimentmarring, monotoning, many-mule-making, mournful, minced-fish and marmalade-masticating Monx. This joyous tirade clearly owes a great deal to the stimulus of alliteration ... (p. 87), 
A writer's decision to impose a pattern of alliteration on a stretch of text has more than just artistic consequences. From the writer's perspective, the rhetorical discipline of following a pattern acts as a stimulus that, as Nash (1980) puts it, urges "the mind to rehearse and methodologically ransack its store of vocabulary" ( $p, 87)$. One might add that rehearsing vocabulary and ransacking the mental lexicon are exactly the sort of things that FL teachers would like learners to be doing.

"Play" is a difficult concept to define, as Cook (1997) has pointed out, and the problem extends to defining "language play." Two types of play have been distinguished by Cook: play at the formal level, and play at the semantic level. This is very similar to Leech's (1969) distinction between "schemes" and "tropes" (pp. 74-76), and it is convenient to adopt Leech's terms here for shorthand reference.

Leech (1969) defines schemes as "foregrounded repetitions of expression" (p. 74), that is, the salient use of phonological, graphological, or formal (grammatical or lexical) patterns. Alliteration, assonance, and rhyme are probably the best-known representatives of this class of rhetorical figure. Tropes are "foregrounded irregularities of content" (Leech, 1969, p. 74), that is, salient deviations of a semantic nature. Metaphor and metonymy are two well-known examples of this class of rhetorical figure.

The idea that play with the form or meaning of the language contributes to language acquisition is not new, at least in L1 circles. Crystal (1998) suggests that it contributes to L1 acquisition at various levels. Play with sounds contributes to pronunciation; play with word endings is valuable for grammar; play with meaning stimulates semantic development; and all varieties of language play contribute to metalinguistic awareness. The joy that children derive from being naughty with the language leads Crystal (1998) to the observation that, "if there is a LAD (a 'Language Acquisition Device,' as proposed by Chomsky and others), it seems to be a BADLAD" (p. 169). A "playful LAD" might be even more apt as it lacks the negative connotations of "bad." "m

Arguments in support of a greater role for language play in FL teaching can be found in a series of articles by Cook (1996), whose main argument is based on the functions of language in society. Language serves ideational and interpersonal functions in everyday life. It is used to manage "the world around us and to form and maintain extensive social relationships" (p. 198). Cook stresses that language also has non-utilitarian functions because it is often used "for recreation, relaxation and pleasure" ( $p$. 198). He characterizes literary texts, advertising, and other discourses that serve this recreational function as "space-filling discourses" because they "fill up the spaces between necessary activity" (p. 198). These discourses fill their space with "whatever seems to please people most ... play with 
the codes of communication themselves" (p. 226).

This function of language play also provides Cook's main argument for using playful discourses in FL teaching. Cook (1994) suggests that the classroom should not be a place where we focus exclusively on utilitarian uses of language, but it should also provide room for students "to escape the demands of social interaction rather than confront them: a protected environment where we can gain confidence and skill with the language code through the pleasures of language play" (p. 114). "Space- filling" discourses in the FL classroom provide an opportunity for "play, a focus on the code away from the demands of immediate social and ideational skills" (Cook, 1994, p. 114) and this play with the code will, in turn, contribute to the student's mastery of the code.

Work with my own students suggests that learners can be quite happy to escape the demands of social interaction and indulge in language play. One language-play activity that I have used consists of giving the students a list of alliterative advertising language with one word in each phrase or clause changed so as to retain the original meaning but remove the alliteration (see Figure 1). Groups of students work together to reconstruct the alliterative original. For example, students were given the phrase "constructed better" and had to figure out an alliterative equivalent like the original "built better." This activity kept a group of first-year college students engaged for around fifteen minutes, and I would like to think that in the course of this engagement they were busy rehearsing words and methodologically ransacking their stores of vocabulary. ${ }^{6}$ (For further discussion of how alliteration in slogans can be exploited, see Picken, 1999).

Figure 1: Alliterative Language-Play Task Using Advertising Language

Changed Version

Original Words (with alliteration)

Example: constructed better

a better piece of butter

dazzling discount bargains

additional economy

fuller taste

luscious underwear

a perfect gift

a wonderful snack

temptingly delicious

Important people take the Times bquilt hetter

(a better bit of butter)

(dazzling discount deals)

(extra economy)

(fuller flavor)

(luscious lingerie)

(a perfect present)

(a super snack)

(Lemptingly tasty)

(Top people take the Times) 
Clearly, this example of language play in the L2 classroom barely provides even anecdotal evidence that play contributes to L2 learning. Although the idea is intuitively appealing, more research is needed before such claims can be made. In addition to the fundamental question of whether play stimulates learning in older learners, two other questions are: (a) what kind of play can be used to engage older learners? Older learners, for example, may be reluctant to spend time chanting children's nonsense rhymes such as "I'm a whale, This is my tail" (Crystal, 1998, p. 165) however much it might contribute to learning; and (b) do different kinds of play contribute to language learning in different ways with L2 learners as Crystal (1998) has suggested that they do in L1 acquisition?

For teachers interested in using advertisements for language play activities, discussions of various kinds of play are available. For schemes in advertising, see Cook (1992) on graphology, and Myers (1994) on play with sounds and sentence patterns. Discussions of tropes have tended to focus on metaphor. Forceville (1996) is a key source here. A comparison of the similarities and differences between metaphor in ads and other discourses can be found in Goatly (1997). Tanaka (1994) discusses puns and also has a chapter on metaphor.

When using ads for language play activities, it is advisable to keep in mind that advertising is a discourse with designs on its audience, and some people do not like this. Negative attitudes to advertising can ruin the fun, as Geis's (1982) response to some humorous TV commercials illustrates: "I suspect that some viewers will find these commercials amusing" (p. 126), Geis, a critic of advertising, evidently did not find the commercials amusing. Teachers should be aware that if such critical attitudes are common among their students, language play activities with ads may fail?

\section{Ads and Culture}

Culture is a difficult concept to define. According to Seelye (1984), "the most widely accepted usage now regards culture as a broad concept that embraces all aspects of the life of man, from folktales to carved whales" (p. 26). He adds that "it is becoming increasingly clear that the study of language cannot be divorced from the study of culture, and vice versa" (p. 26). A clear statement of the relationship between language and culture can be found in Kramsch (1993), who proposes that culture is anchored "in the very grammar we use, the very vocabulary we choose, the very metaphors we live by" (p. 8 ).

The practical implication of this culture-based view of language is that the FL learner is inevitably confronted with a different culture when 
learning a language. Kramsch (1993) discusses how to deal with this confrontation by considering what she calls the German hermeneutic tradition, which stresses that language learners should not only learn to communicate effectively and learn about others while doing so, but that they should also get to understand themselves in the process. She sees this understanding as a "third place' ... that grows in the interstices between the cultures the learner grew up with and the new cultures he or she is being introduced to" (Kramsch, 1993, p. 236). Learners, in other words, have to find a place for themselves somewhere between their own cultures and the target culture.

Kramsch suggests ways in which foreign language teachers can facilitate this process. She is particularly interested in activities that help to bring out cultural content, and these ideas should be of interest even to those who do not accept her thesis about helping students find a "third place" between cultures. Many of Kramsch's suggestions involve focusing on particular dimensions of texts. In her chapter on teaching the literary text, for example, she discusses the value of varying the text's medium, genre, and audience. In a following chapter she also uses the approach of varying the audience of an advertisement to help learners become aware of its underlying cultural assumptions. Meinhof (1998) supports this technique for similar reasons.

An advertisement for the Guardian provides a good illustration of how Kramsch's ideas can be applied. The advertisement shows two men and a woman sitting on a bench reading newspapers while they wait to be interviewed for a job. The man with the Guardian exudes confidence. Sitting with his legs crossed casually and his newspaper spread wide open, he occupies the right half of the bench while the other two candidates huddle uncomfortably on the left. The advertisement asks, "Who would you like to interview first: the one with the Telegraph, the one with the Times, or the one with the mind of his own?" (Link, 1992, p. 93).

The ad was designed to appeal to a British audience, but would this approach work in Japan? The answer would depend on the extent to which "having a mind of your own" is considered an asset. In Japan, employers might be more interested in team players or graduates of top universities, especially for entry-level positions. If the students feel that this is the case, they would have to rewrite the ad accordingly, ensuring that it would appeal to a Japanese audience while sticking as closely as possible to the question pattern in the original ad. In this way, the task can highlight differences in underlying cultural values or expectations, Advertisements, then, would appear to be a valuable resource for culture-related work. In order to maximize the value of the contribu- 
tion, however, further research is needed. First, the role of ads needs to be clarified. For example, Kramsch gives detailed suggestions on how ads and other authentic materials can be used but she says very little about how to select them or what to use them for. The Coca Cola advertisement that she discusses in her book was selected because it was "found particularly appropriate for Russian learners of American English because of its rich cultural connotations and its potential differences with the (then) Soviet cultural imagination" (Kramsch, 1993, p. 211). Here one needs to ask why the ad was felt to be particularly appropriate for this group of learners and what differences regarding the Soviet imagination were highlighted.

Advertising research could make a worthwhile contribution here. Corpus research could help to clarify whether there are particular values that the advertisements of a given target culture tend to appeal to, and it could also provide teachers with representative examples of ads that exploit these values. This research would help teachers make informed decisions about how they could use advertisements and save them some of the trouble of searching for relevant ads. Some work has already been done in this area. Vestergaard and Schrøder (1985) suggest that women are addressed in terms of, among others, the ideal of domesticity, the beauty ideal, and the ideal of the independent woman. Unfortunately, their findings are too general for practical application. "Domesticity" may still be used as an appeal today, but what are the specifics? How is it typically represented in terms of relationships with other members of the family and roles within those relationships? Only at this level of specificity are we likely to find meaningful differences between representations of domesticity in different cultures. Corpus research could provide details and examples.

When using ads for culture work, teachers should keep in mind that ads may not simply be reflecting a culture but also contributing to the values and patterns of behavior of members of that culture. This point is made by Fairclough (1989), who argues that advertising has actually built the consumption community because it has "provided the most coherent and persistent models for consumer needs, values, tastes and behaviour" (p. 207). Similarly, O'Barr (1994) suggests that it is a twoway relationship: "Depictions of society in advertisements have their basis in the social order, and the social order is continually re-created by reference to ideals in advertisements and elsewhere about what it should be" (p. 4). To return to Vestergaard and Schrøder's (1985) ideal of domesticity, for example, it is important to realize that advertisers may be selling consumers a particular domestic ideal and not just exploiting a widely shared one. Against this background Meinhof (1998) warns that 
"media discourse provides a fertile but treacherous ground for cultural learning. It can seem so close to everyday life as to almost efface any difference; it can mislead us into thinking that we are encountering the real world" (p. 9). Clearly, it is essential to come to terms with the relationship between ads and the real world. If ads are a distorted mirror of reality, teachers need to be aware of this in order to be able to help their students "see through" the distortions.

\section{Conclusion}

This paper has attempted to provide a critical examination of the main arguments for using advertisements in FL teaching within the areas of language awareness, language play, and culture learning. Language awareness researchers have stressed that successful communication is a complex affair because people play with the rules of language in a range of ways. Mastering a language, therefore, involves more than a mastery of rules, and learners need to be aware of this and learn how to deal with it in a foreign language. Learning to communicate in a foreign language is also hard work, and learners are likely to feel the need to take a break. Language play offers a meaningful way of doing so, as Cook (1994) has suggested. The possibility that this kind of play also contributes directly to language acquisition opens up a potentially major area for second language acquisition research. Learning to communicate in a foreign language also means that learners must come to terms with the culture that informs the target language at every level.

Researchers in all three areas have proposed the use of advertisements to help learners address these needs. The often literary quality of advertising discourse can provide opportunities to help learners become aware of how the rules of language can be stretched and what this may be designed to achieve. This playfulness also makes advertising a great potential source of materials for language-play activities, Finally, advertisements have a complex relationship with the culture for which they were produced, and this can provide an excellent starting point for culture-related work.

Advertising research provides considerable support for these uses of ads, but it also points to some areas where further research is needed or where problems may occur. Advertising may have literary qualities, but it is also a highly visual discourse and one with designs on its audience. These characteristics may give rise to problems when ads are used for language awareness work and for language play purposes. Researchers could contribute to an understanding of these problems by providing descriptions of the complex uses of visual elements in ads and by exam- 
ining the visual and visual/verbal literacy problems that these may give rise to among FL learners. With regard to using ads for culture-related work, teachers need to be aware of the complex two-way relationship between ads and cultural values,

Corpus research could make a significant contribution to an understanding of many of the issues discussed in this paper such as how advertisements play with visual and verbal elements and how they exploit cultural values. One problem here is that the corpus linguistics literature does not discuss the specifics of creating a corpus of ads in sufficient detail. Stubbs (1992) devotes two pages to the topic, but his comments are puzzling. He criticizes Cook (1992), who never claims that his research was corpus-based, and recommends Myers (1994) even though the latter specifically states that his ads are "not offered as a representative sample" (Myers, 1994, p. vii). Useful discussions of many of the issues that come up in advertising corpus design can be found in the content analysis literature. Riffe, Lacy, and Fico (1998) provides a good starting point.

\section{Acknowledgments}

I would like to thank the three anonymous reviewers of the paper and my colleague Mary Altbaus for the many improvements they suggested.

Jonathan D. Picken is an associate professor in the Department of English at Tsuda College in Tokyo, where he teaches EFL courses. He is interested in the use of mass media discourse in EFL.

\section{Notes}

1. Carter and Nash's (1990) six criteria of literariness are: (1) medium dependence (the degree to which a text depends on other media, especially visual ones); (2) re-registration (openness to voices from other discourses); (3) interaction of levels: semantic density ("a text that is perceived as resulting from the additive interaction of several superimposed codes and levels is recognized as more literary than a text where there are fewer levels at work, or where they are present but do not interact," (p. 39); (4) polysemy (the degree to which the text can be read in more than one way); (5) displaced interaction (the degree to which speech acts in the texts are seen as direct, which they tend not to be in literary texts); and (6) discourse patterning (the degree to which discoursal patterns can be seen to represent the content).

2. Other examples can be found in Carter, Goddard, Reah, Sanger, and Bowring (1997).

3. This is also a good example of "displaced interaction," one of Carter and Nash's (1990) criteria of literariness. The speech acts of thanking Mr. van Tune and complaining to him are clearly not intended to be direct.

4. For the sequence of activities to work, it is essential to use ads that re- 
register familiar genres such as the business letter. Even then unexpected problems may occur. When I recently used advertisements to teach freshman students in a content course the concept of re-registration, only two out of 24 students made the link between an anti-smoking ad and the infamous Marlboro Man advertisements that it was re-registering. This ruled out smallgroup discussion of how this particular example had played with its original. (Because the focus was on the concept of re-registration, the students were not expected to rewrite any of the ads.)

S. In the field of cognitive science Gibbs (1994) has proposed that it is not just the LAD, but also the human mind itself, that works in a fundamentally creative or poetic way. He is particularly interested in the role of metaphor and suggests that "our basic metaphorical conceptualizations of experience constrain how we think creatively and express our ideas in both everyday and literary discourse" (p. 8). For two important attempts to make a connection between metaphor research and applied linguistics, see Cameron and Low (1999a; 1999b).

6. In order to ensure that students ransack their mental lexicons, the use of electronic dictionaries should be forbidden during the activity. A majority of my students now have them, and this year I discovered that they were using their dictionaries' thesaurus function to get answers, even though they knew the target words used in the task. This defeated the purpose of the exercise,

7. In my work with ads in EFL and content courses I have not experienced negative attitudes towards ads among Japanese college students. Frustration does occur sometimes when the ad is too puzzling, but this is normally counterbalanced by laughter or cries of appreciation when the students finally understand the meaning.

8. A detailed discussion of responses to and problems encountered with tasks like this can be found in Kramsch (1993). It should be noted that Kramsch was working with groups of German and Russian language teachers and their responses were presumably more sophisticated than what one could expect from most university students in language courses in Japan.

\section{References}

Bruthiaux, P. (1996). The discourse of classified advertising: Exploring the nature of linguistic simplicity. New York: Oxford University Press.

Cameron, L, \& Low, G. (1999a). Metaphor Language Teaching, 32, 77-96.

Cameron, L., \& Low, G. (Eds.). (1999b). Researching and applying metaphor Cambridge: Cambridge University Press.

Carter, R., Goddard, A., Reah, D., Sanger, K., \& Bowring, M. (1997). Working with texts: A core book for language analysis, London: Routledge.

Carter, R., \& McCarthy, M. (1995). Discourse and creativity: Bridging the gap between language and literature. In G. Cook \& B. Seidlhofer (Eds.), Principle and practice in applied linguistics: Studies in bonour of H. G. Widdowson (pp. 303-321). Oxford: Oxford University Press.

Carter, R. \& Nash, W. (1990). Seeing through language: A guide to styles of English writing. Oxford: Blackwell. 
Cook, G. (1992). The discourse of advertising. London: Routledge.

Cook, G. (1994). Language play in advertisements: Some implications for applied linguistics. In D. Graddol \& J. Swann (Eds), Evaluating language: $\mathrm{Pa}$ pers from the annual meeting of the British Association for Applied Linguistics beld at the University of Essex, September 1992 (pp. 102-116). Clevedon, UK. BAAL/Multilingual Matters.

Cook, G. (1996). Language play in English, In J. Maybin \& N. Mercer (Eds,), Using English: From conversation to canon (pp. 198-227). London: Rutledge/ Open University

Cook, G. (1997). Language play, language learning. ELT Journal, 51, 224-231.

Coyne, P. (Ed.). (1997). 1997 advertising annual (special issue). Communication Arts, 39 (7).

Crystal, D. (1998). Language play. London: Penguin.

Davis, R. (1997). TV commercial messages: An untapped video resource for content-based classes. The Language Teacher, 21 (3), 13-15.

Doering, E.J. (1993), Gaining competence in communication and culture through French advertisements. French Review, 66, 420-432.

Fairclough, N. (1989). Language and power London: Longman.

Forceville, C (1996), Pictorial metaphor in advertising, London: Routledge.

Geis, M.L. (1982). The language of television advertising. New York: Academic Press.

Gibbs, R.W., Jr. (1994). The poetics of mind: Figurative thought, language, and understanding, Cambridge, UK: Cambridge University Press.

Goatly, A. (1997). The language of metaphors. London: Routledge.

Goddard, A. (1998), The language of advertising: Written texts. London: Routledge.

Goodman, S. (1996). Visual English. In S. Goodman \& D. Graddol (Eds.), Redesigning Englisb: New texts, new identities (pp. 38-72). London: Routledge/Open University.

Hewings, M. (1991). The interpretation of illustrations in ELT materials. ELT Journal, 45, 237-244.

Jakobson, R. (1988). Linguistics and poetics. In D. Lodge (Ed), Modern critictsm and theory: $A$ reader (pp, 32-57). London: Longman.

Kramsch, C. (1993). Context and culture in language teaching. Oxford, UK: Oxford University Press.

Leech, G.N. (1966). English in advertising: A linguistic study of advertising in Britain. London: Longman.

Leech, G.N. (1969). A linguistic guide to English poetry. London: Longman. Link, L.J. (1992), Rbetorical devices in print advertising. Tokyo: Kenkyusha.

McCarthy, M \& Carter, R. (1994). Language as discourse: Perspectives for language teaching. London: Longman.

McRae, J. (1996). Representational language learning: From language awareness to text awareness. In R. Carter \& J. McRae (Eds), Language, literature and the learner: Creative classroom practice (pp. 16-40). London: Longman.

Meinhof, U.H. (1998). Language learning in the age of satellite television. Oxford, UK: Oxford University Press.

Mollica, A. (1979). A tiger in your tank: Advertisements in the language class- 
room. Canadian Modern Language Review, 35, 691-743.

Myers, G. (1994). Words in ads. London: Edward Arnold.

Nash, W (1980). Designs in prose: A study of compositional problems and methods. London: Longman.

O'Barr, W.M. (1994). Culture and the ad: Exploring otherness in the world of advertising. Boulder, CO: Westview Press.

Picken, J.D (1999). State of the ad: The role of advertisements in foreign language teaching, ELT Journal, 53, 249-255.

Riffe, D., Lacy, S., \& Fico, F.G. (1998). Analyzing media messages: Using quantitative content analysis in research. Mahwah, NJ: Lawrence Erlbaum.

Seelye, H.N. (1984). Teaching culture: Strategies for intercultural communica. tion. Lincolnwood, IL: National Textbook Company.

Stubbs, M. (1992). Text and corpus analysis: Computer-assisted studies of language and culture. Oxford: Blackwell.

Tanaka, K. (1994), Advertising language: A pragmatic approach to advertisements in Britain and Japan. London: Routledge.

Vestergaard, $\mathrm{T}_{+}$\& Schroder, $\mathrm{K}$. (1985). The language of advertising. Oxford: Basil Blackwell.

Yaguello, M. (1998). Language through the looking glass: Exploring language and linguistics. Oxford: Oxford University Press.

(Received October 7, 1999; revised July 5, 2000) 